The Bulletin of the Dnipropetrovsk university. Series: Management of innovations

Issue 7, Volume 24 (2016)

DOI: $10.15421 / 191620$

Received: 19 Sep 2016

Accepted: 26 Nov 2016

Published: 25 Dec 2016

\title{
The « 4 Cs» of cultural diversity in consumer research: a literature review and research agenda
}

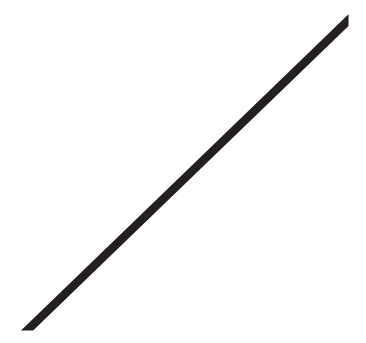

L. Ivanov ${ }^{\ddagger}$

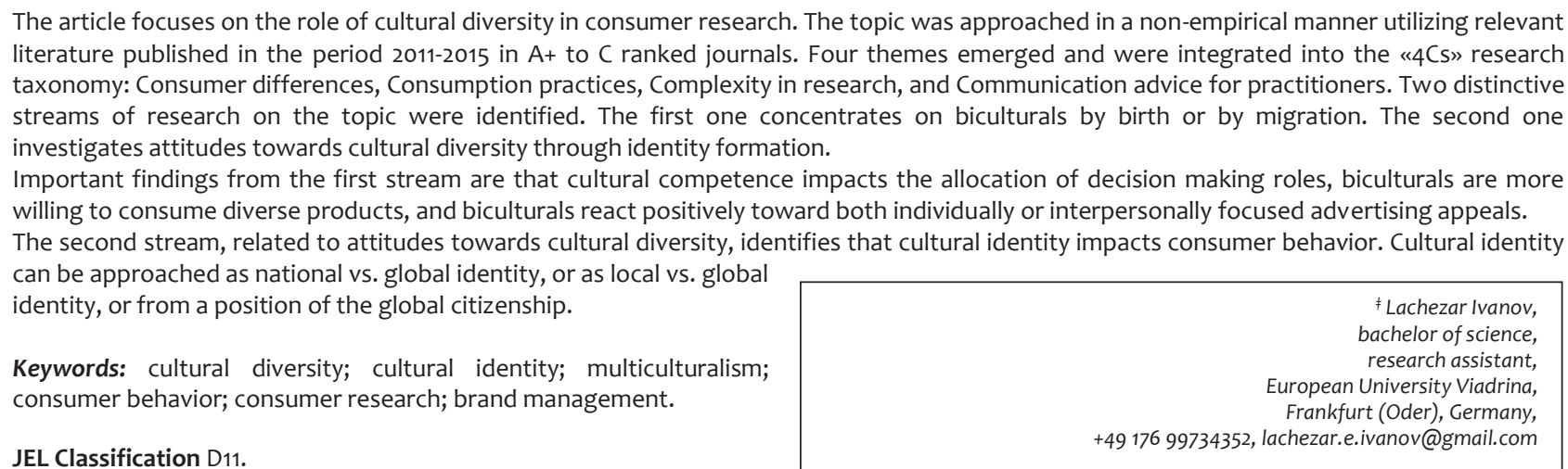




\section{«4Сs» культурної різноманітності у вивченні споживачів: огляд літератури і досліджень}

\section{Л. Іванов}

Європейський університет Віадрина, Франкфурт-на-Одері, Німеччина

Статтю присвячено характеристиці ролі культурної різноманітності у вивченні споживача. Тему було досліджено за допомогою неемпіричного підходу на основі даних наукових статтей, опублікованих у 2011-2015 рр. у журналах з рейтингом від А + до С. У наукову систематизацію включено 4 аспекти («4 (S»): споживчі відмінності (Consumer differences), характер споживання (Consumption practices), рівень складності в галузі наукових досліджень (Complexity in research), а також поради для практичного застосування в комунікації зі споживачами (Communication advice for practitioners). Виявлено два основні напрямки, в яких розвивалися дослідження з даної теми. Перше з них концентрується на індивідах, які належать до двох різних культур (внаслідок народження або імміграції). Другий напрямок досліджує ставлення до культурної різноманітності шляхом формування культурної ідентичності.

Важливим результатом у межах першого напрямку досліджень було виявлення впливу культурної компетенції на розподіл ролей прийняття рішень: індивіди, що належать до двох культур, більшою мірою схильні споживати різноманітні продукти. Крім того, вони позитивно реагують як на індивідуальні, так і на міжособистісні рекламні повідомлення. Другий напрямок виявив вплив культурної ідентичності на поведінку споживачів. Культурна ідентиченість може бути визначена як протиставлення національної приналежності глобальній, протиставлення локальної приналежності глобальній або розглянута з позиції космополітизму.

Ключові слова: культурна різноманітність; культурна ідентичність; мультикультуралізм; поведінка споживачів; дослідження споживачів; бренд-менеджмент.

\section{«4Сs» культурного разнообразия в изучении потребителей: обзор литературы и исследований}

\author{
Л. Иванов \\ Европейский университет Виадрина, \\ Франкфурт-на-Одере, Германия
}

Статья посвящена роли культурного разнообразия в изучении потребителя. Эта тема была исследована с помощью неэмпирического подхода на основе данных научных статей, опубликованных в 2011-2015 гг. в журналах с рейтингом от А+ до С. В научную систематизацию были включены 4 аспекта («4 Cs»): потребительские различия (Consumer differences), характер потребления (Consumption practices), уровень сложности в области научных исследований (Complexity in research), а также советы для практического применения в коммуникации с потребителями (Communication advice for practitioners). Были выявлены два основных направления, в которых развивались исследования по данной теме. Первое из них концентрируется на индивидах, принадлежащих к двум различным культурам (вследствие рождения или иммиграции). Второе направление исследует отношение к культурному разнообразию путем формирования культурной идентичности. Важным результатом в рамках первого направления исследований было выявление влияния культурной компетенции на распределение ролей принятия решений: индивиды, принадлежащие к двум культурам, в большей степени склонны потреблять разнообразные продукты. Кроме того, они положительно реагируют как на индивидуальные, так и межличностные рекламные сообщения.

Второе направление выявило влияние культурной идентичности на поведение потребителей. Культурная идентичность может быть определена как противопоставление национальной принадлежности глобальной, противопоставление локальной принадлежности глобальной или рассмотрена с позиции космополитизма.

Ключевые слова: культурное разнообразие; культурная идентичность; мультикультурализм; поведение потребителей; исследования потребителей; бренд-менеджмент. 


\section{Introduction}

$\mathrm{s}$ countries and businesses are becoming more culturally A diverse, the number of people who can be described as $\checkmark$ multiculturals or biculturals relative to monoculturals is increasing (Lau-Gesk, 2013) [1]. Cultural diversity creates both opportunities and challenges for marketers. For instance, global and local brands and related products are in severe competition in diverse environments (Tu, Khare, \& Zhang, 2012) [2]. In the present paper, an overview of studies related to cultural diversity is provided. The paper explores the topic trough the themes of consumer differences, their implication for consumption practices, complexity in research, and communication advice for practitioners. The four lenses form the four C's of cultural diversity in consumer research as argued in the present paper. The first section provides important definitions. A critical overview of relevant studies follows in the consequent sections. The concluding section provides a summary and discusses limitations of the assessed literature. It also offers ideas for further research.

\section{Definitions}

$\mathrm{n}$ order to define cultural diversity, one needs to explore first I the concept of culture. According to (Woodside, \& Zhang, 2013) [3], more than 200 definitions of culture exist. The two scholars define culture as "conjunctive concept that implies that each nation, society, or group has a unique combination of shared values, attitudes, beliefs, practices, and use of language that identifies its members from members of other cultures" (Woodside, \& Zhang, 2013) [3, p. 264].

Kipnis et al. (2012) [4, p. 427] define culturally diverse environments as «societies where multiple cultures co-exist». The emphasis is on the co-existence of sub-cultures in a society. As an opposite to cultural diversity is regarded the concept of a «monoculture».
Research should go, however, beyond this simple differentiation that according to Kipnis et al. (2012) [4] loses importance and does not effectively captures the complexity of cultural affinities within groups. Cultural diversity, thus, contains highly contested meanings. Consumers interconnect those meanings and accommodate them in the process of construction of their own identities (Russell, Schau, \& Crockett, 2013) [5, 2013].

\section{Methodology}

$\mathrm{n}$ order to explore the research question, a literature analysis I was performed. After a keyword search in the EBSCO and the ScienceDirect journal databases, a total of 37 articles was obtained. The search terms included «cultural diversity» and related constructs such as «cultural openness», «cosmopolitanism», «world-mindedness», «consumer ethnocentrism», «consumer animosity», and "consumer racism» (Gammoh et al., 2011; Kipnis et al., 2012; Bartikowski and Walsh, 2015) $[6 ; 4 ; 7]$. After assessing the relevance of the articles, a total of 7 empirical papers, published in the period 2011-2015 in A+ to C ranked journals (according to the VHB-JOURQUAL ranking), were selected for further thorough evaluation. Each paper was systematically reviewed. Afterwards it was decided whether it relates to the concept of cultural diversity in consumer research. Prior research revealed a pattern of key themes. In particular, four topics emerged that reflect the scope of research on cultural diversity in consumer studies: Consumer differences, Consumption practices, Complexity in research, and Communication advice for practitioners - the $4 \mathrm{Cs}$. Two distinctive streams of research on the topic were identified. The first one concentrates on biculturals by birth or by migration and the second one investigates attitudes towards cultural diversity trough identity formation. The following sections elaborate on each of the $4 \mathrm{Cs}$ themes, as inferred from past research, and combine them in a research framework (Table 1).

Table 1

The 4 Cs of cultural diversity in consumer research

\begin{tabular}{|c|c|c|c|c|}
\hline Article & $\begin{array}{l}\text { Consumer } \\
\text { differences }\end{array}$ & Consumption practices & $\begin{array}{l}\text { Complexity in } \\
\text { research }\end{array}$ & $\begin{array}{l}\text { Communication } \\
\text { advice }\end{array}$ \\
\hline (Cross, \& Gilly, 2014) [9] & $\begin{array}{l}\text { migrant vs. } \\
\text { monocultural }\end{array}$ & $\begin{array}{l}\text { Cultural competence impacts the } \\
\text { allocation of decision making roles. }\end{array}$ & $\begin{array}{l}\text { Survey and in-depth } \\
\text { interviews }\end{array}$ & $\begin{array}{l}\text { Considering cultural } \\
\text { competency when } \\
\text { deciding on a selling } \\
\text { strategy }\end{array}$ \\
\hline (Cross, \& Gilly, 2013) [8] & $\begin{array}{l}\text { bicultural vs. } \\
\text { monocultural }\end{array}$ & $\begin{array}{l}\text { Biculturals are more willing to } \\
\text { consume diverse products. }\end{array}$ & In-depth interviews & \\
\hline $\begin{array}{l}\text { (Kipnis, Emontspool, \& } \\
\text { Broderick, 2012) [4] }\end{array}$ & $\begin{array}{l}\text { migrant vs. } \\
\text { monocultural; } \\
\text { cultural } \\
\text { orientations }\end{array}$ & $\begin{array}{l}\text { Consumers differentiate between } \\
\text { foreign and global culture and } \\
\text { consume accordingly. }\end{array}$ & $\begin{array}{l}\text { In-depth interviews } \\
\text { and accompanied } \\
\text { shopping trips }\end{array}$ & $\begin{array}{l}\text { Using the framework } \\
\text { for segmentation and } \\
\text { communication }\end{array}$ \\
\hline$($ Lau-Gesk, 2013) [1] & $\begin{array}{l}\text { bicultural vs. } \\
\text { monocultural }\end{array}$ & $\begin{array}{l}\text { Biculturals react positively toward } \\
\text { both individually or interpersonally } \\
\text { focused advertising appeals. }\end{array}$ & Experiment & \\
\hline $\begin{array}{c}\text { (Bartikowski, \& Walsh, 2015) } \\
\text { [7] }\end{array}$ & $\begin{array}{l}\text { national vs. } \\
\text { global identity }\end{array}$ & $\begin{array}{l}\text { Cultural identity orientation } \\
\text { informs consumer behavior. }\end{array}$ & Survey & $\begin{array}{l}\text { Using UDO when } \\
\text { tailoring } \\
\text { communication } \\
\text { efforts }\end{array}$ \\
\hline (Tu, Khare, \& Zhang, 2012) [2] & $\begin{array}{l}\text { local vs. global } \\
\text { identity }\end{array}$ & $\begin{array}{l}\text { Cultural identity informs consumer } \\
\text { behavior. }\end{array}$ & $\begin{array}{l}\text { Surveys and } \\
\text { experiment }\end{array}$ & $\begin{array}{l}\text { Using the local-global } \\
\text { identity scale for } \\
\text { segmentation and } \\
\text { positioning }\end{array}$ \\
\hline $\begin{array}{c}\text { (Gammoh, Koh, \& Okoroafo, } \\
\text { 2011) [6] }\end{array}$ & $\begin{array}{l}\text { high vs. low } \\
\text { belief in global } \\
\text { citizenship } \\
\text { (BGC) }\end{array}$ & $\begin{array}{l}\text { Consumers prefer global consumer } \\
\text { culture positioning (GCCP) } \\
\text { compared to LCCP. The effect is } \\
\text { moderated by BGC. }\end{array}$ & Experiment & $\begin{array}{l}\text { Using global GCCP for } \\
\text { consumers high on } \\
\text { BGC }\end{array}$ \\
\hline
\end{tabular}




\section{Results}

\section{Consumer differences}

s previously mentioned, scholars from the first stream of A research differentiate between two groups of consumers: biculturals vs. monoculturals. Biculturals in these studies are either migrants, who tend to develop predisposition towards both their country of origin and the country they migrated to, or the offspring of migrants and mainstream monoculturals, who are bicultural by birth (Cross, \& Gilly, 2013) [8].

According to demographics data in the USA, there is a considerable increase of the count of binational households. This phenomenon and its implications for marketers, however, are underinvestigated (Cross, \& Gilly, 2014) [9]. Cross, \& Gilly (2014) [9] claim for the importance of the household as a decision-making and consumption unit. The two scholars criticize prior literature for regarding the household as an entirely culturally homogeneous unit with regard to its composition. The authors further claim that past research in household decision making was narrowly focused on the influence of gender. Cross, \& Gilly, (2014) [9] investigate cultural diversity within bi-national households in the USA. In the research, one of the partners is migrant to the country and the other partner is born and raised in the USA.

Cross, \& Gilly (2013) [8] compare multicultural consumers with mainstream consumers. In particular, the two scholars investigate the effect of biculturalism on decision making and food consumption patterns among bicultural from birth children. The authors define bicultural consumers as «immigrants, the children of immigrants, members of ethnic minorities, long-term expatriates, globally mobile individuals, bilinguals and the children of binational families" (Woodside, \& Zhang, 2013) [3, p. 60]. According to the authors, bicultural children struggle to incorporate two distinctive views in their consumption behavior. These are related to either the world of their diverse parents and the society they live in.

Kipnis et al. (2012) [4] conceptualize a Typology of Consumer Cultural Orientations as framework for ethnic consumption. According to the authors, both mainstream and migrant consumers can cultivate local, global and foreign cultures affinities through direct (for example - travel) and indirect (for example - media) experiences. These affinities impact consumers' consumption of products connected to the affinity culture. Kipnis et al. (2012) [4, p. 428] define local culture as «ways of life and systems of values, beliefs and symbols considered originating from, unique to and mainstream in the country of residence», global culture - «a homogenic set of values, beliefs, lifestyle and symbols shared in a unified manner by individuals across countries», and foreign culture - «system of values, beliefs and symbols that comes from a definable cultural source(s) (country or cultural group) and is different from local culture». In addition, combinations between all of the three orientations are possible enabling the existence of bi- and multicultural orientations for consumers irrespective of their ethnic belonging. Kipnis et al. (2012) [4] argue for the existence of four additional orientations local-global, local-foreign, global-foreign, and full integration. Global-foreign oriented consumers employ both foreign and global cultures simultaneously but not interchangeably. Conversely, local-foreign orientation implies openness to outside cultures, but distancing from global culture (Kipnis et al., 2012) [4].

Lau-Gesk (2003) [1] investigate the impact of individually or interpersonally focused advertising appeals on biculturals and monoculturals. In the research, biculturals are defined as individuals «with equally developed East Asian and Western cultural dispositions» (Lau-Gesk, 2003) [1, p. 301]. Individuals impacted by the East Asian culture are reported to develop a highly accessible interdependent cultural self, whereas individuals influenced by Western culture are shown to develop highly accessible independent cultural self. The more accessible cultural predisposition «dominates the way individuals think, feel, and are motivated» (Lau-Gesk, 2003) [1, p. 302]. Biculturals are expected to have two equally accessible in memory cultural predispositions.

The second stream of research investigates attitudes towards cultural diversity trough identity formation. The study of Bartikowski, \& Walsh (2015) [7] belongs to that category. The two authors explore effect of consumers' national and global identities on purchase behavior. In particular, they are interested in consumers' unwillingness to buy foreign products in place of domestic alternatives. In the model, national identity is connected to the concept of ethnic identity and, thus, to local or regional affiliation.

Global identity has a connection with individuals' selfcategorization to a global cultures and its related meanings and practices. The authors further use the three-dimensional concept of consumers' universal-diverse orientation (UDO) as a mediator of the relationship between consumers' identity orientation and the reluctance to purchase foreign products. The three UDO dimensions are diversity of contact, relativistic appreciation, and discomfort with differences.

Consumers tend to develop predisposition towards local and global products. Tu et al. (2012) [2] develop and test an 8-item scale for measuring consumers' local-global identity. Local identity is defined as when «consumers have faith in and respect for local traditions and customs, recognize the uniqueness of local communities, and are interested in local events» (Tu et al., 2012) [2, p. 36]. Global identity is defined as when «consumers believe in the positive effects of globalization, recognize the commonalities rather than dissimilarities among people around the world, and are interested in global events» (Tu et al., 2012) [2, p. 36]. The authors test the scale against and prove it is distinct from the related constructs of consumer ethnocentrism, nationalism, and global consumption orientation.

Gammoh et al. (2011) [6] investigate the effect of communication strategies on consumers' evaluation of a fictitious brand. In particular, they compare global consumer culture positioning (GCCP) and local consumer culture positioning (LCCP) as conceptualized by Alden et al. (1999) [10] for consumers who differ in their level of belief in global citizenship (BGC) defined by Strizhakova et al. (2008) [11, p. 59] as the «belief that global brands create an imagined global identity that a person shares with likeminded people». Alden et al. (1999) [10] argue for the existence of foreign consumer culture positioning (FCCP). It is, however, not examined in the study of Gammoh et al. (2011) [6]. Alden et al. (1999) [10, p. 77] define GCCP as "one that identifies the brand as a symbol of a given global culture - for example, the post-second world war, cosmopolitan segment» and LCCP as «a strategy that associates the brand with local cultural meanings, reflects the local culture's norms and identities, is portrayed as consumed by local people in the national culture, and/or is depicted as locally produced for local people».

\section{Consumption practices}

ross, \& Gilly (2014) [9] find that cultural competence defined C as a knowledge of the country of residence impacts the 4 allocation of decision making roles. The spouse who has cultural competence is regarded as an expert and in possession of cultural capital. The authors mapped the results of the conducted surveys on a two-dimensional decision plot. It is noticeable that most of the decisions are jointly taken (both autonomic and syncratic). With regard to autonomic decisions, wives have dominance over the choice of children's toys and clothing and home decoration. Men have a dominant influence in the choice of computer equipment (Cross, \& Gilly, 2014) [9].

Cross, \& Gilly (2014) [9] split the data and mapped it again for families with American husbands and immigrant wives and families with immigrant husbands and American wives. The general pattern of results remained similar to the non-split sample. In households where the husband is American and the 
wife is immigrant, investment decisions are either taken jointly or by the husband. Food purchase decisions are dominated by the wife in American husband/ immigrant wife households. These decisions are, however, taken jointly in immigrant husband/ American wife households (Cross, \& Gilly, 2014) [9].

One of the themes that emerges in the research of Cross, \& Gilly (2013) [8] is "openness», by which the authors imply that bicultural individuals tend to be more willing to engage in consumption of diverse products and experiences.

According to Kipnis et al. (2012) [4], consumers in culturally diverse environments may develop one or more cultural affinities that will ultimately impact their purchase behavior. Furthermore, consumers can meaningfully differentiate between the concepts of foreign and global culture. They employ them in materializing identity projects.

The results of the study of Lau-Gesk (2003) [1] suggest that bicultural individuals react positively toward both individually or interpersonally focused advertising appeals. In particular, biculturals react to Western cultural symbols as monocultural Westerners, and to East Asian cultural symbols - as monocultural East Asians. The author explains this finding trough the two equally developed and accessible cultural predispositions. One of two predispositions that is congruent with the appeal gets temporarily activated by the cultural clues embedded in the persuasion appeal (Lau-Gesk, 2003) [1]. The study of Lau-Gesk (2003) [1] demonstrates that consumers can shift between and access different selves across different situations according to cues embedded in the environment. Thus, behavior that may sometimes appear inconsistent and irrational may be explained trough shifting between different selves in response to situational cues. This finding is of significance for the development and understanding of the self concept threated by past research as a rather stable construct (Lau-Gesk, 2003) [1].

Bartikowski, \& Walsh (2015) [7] argue that unwillingness to buy foreign products increases with a stronger national identity. It, however, does not necessarily decrease with a stronger global identity. This asymmetry can be successfully interpreted by including UDO as a mediator variable. Positive and negative indirect effects may cancel each other out. An important role plays the relativistic appreciation dimension, since both stronger national and global identities lead to stronger relativistic appreciation, and ultimately to higher reluctance to purchase foreign products. While in the case of high national identity the result does not seem surprising, Bartikowski, \& Walsh (2015) [7] provide an explanation for the case of high global identity. According to them, individuals scoring high on that scale may be more aware of global problems whose solution they see in the consumption of domestic products.

According to Tu et al. (2012) [2], when consumers score high on global identity (naturally or by being primed), they prefer global brands and products as measured by product attractiveness and liking. Consequently, consumers with high local identity show preferences towards local brands and products Tu et al. (2012) [2].

The results of the study of Gammoh et al. (2011) [6] demonstrate that consumers prefer GCCP compared to LCCP as indicated by the increase in brand attitude, purchase intention, worth of mouth, and brand prestige. The effect is moderated by the individual consumers' differences variable of level of belief in global citizenship (BGC). Consumers who score high on BGC perceive themselves as less local and show more positive predisposition towards globally perceived products. They, thus, show a more positive response towards GCCP branded products.

\section{Complexity in research}

ust as for cross-cultural research, for intra-cultural studies J also apply the importance of ensuring equivalence of constructs, measurement, and data collection (Hult, 2014)

[12] between different sub-cultural groups.
Some scholars expect construct equivalence due to the common language. However, the validation and pre-testing of scales should employ samples from various sub-cultures or cultures. For example, Tu et al. (2012) [2] validate the local-global identity scale by testing it in three different countries with both student and non-student samples. Gammoh et al. (2011) [6] conduct their study in the USA and India.

Measurement equivalence is related to wording, scaling, and scoring of responses (Hult, 2014) [12]. Scholars are advised to use appropriate translation techniques (e.g. translation and backtranslation in the study of Lau-Gesk (2003) [1]) in order to preserve the meaning and ensure correct interpretation and equivalence of the measured constructs among subjects from different subcultural contexts.

In order to enhance collection equivalence, some scholars employ student samples for the comparison of sub-cultures. The reason is to suppress the variance within the sub-groups, since student samples tend to be of a rather homogeneous nature. It is, however, doubtful that student samples are representative of the respective sub-cultures. Therefore, comprehensive analysis should determine whether the results are comparable.

As shown in Table 1, only few papers mainly from the second stream of research investigating attitudes towards cultural diversity trough identity formation adopt an experimental research design. Hence, the rest of the papers are hindered with regard to the definition of cause and a consequence (Bartikowski, \& Walsh, 2015) [7].

\section{Communication advice}

ith regard to communication, Cross, \& Gilly (2014) [9] advice W for taking into account cultural competency when salespeople have to decide on a selling strategy for a household. A salesperson should consider not only gender roles, but also the background of each spouse.

According to Kipnis et al. (2012) [4], marketing researchers and practitioners may benefit from using the developed Typology of Consumer Cultural Orientations for segmentation and for the development of brand communication strategies aimed at multicultural consumers.

Bartikowski, \& Walsh (2015) [7] propose that marketers may benefit from using UDO when tailoring their communication efforts. In particular, for subjects scoring high on diversity of contact, they suggest the use of foreign appeals. When consumers are either high on relativistic appreciation or discomfort with differences, the authors recommend emphasizing domestic appeals. Bartikowski, \& Walsh (2015) [7] further advice for making cultural identities more salient through the use of priming in advertising that can prompt selfcategorization. In particular, one can make use of country-oforigins slogans to increase national («Made in Germany») or global (HSBC - the world's local bank) identities.

According to Tu et al. (2012) [2], marketing practitioners need to know consumers' orientation towards local versus global products in order to effectively adapt brand positioning strategies. They suggest the reliance on the developed by them local-global identity scale for the purposes of segmentation. In addition, the scholars argue for the use of advertising, PR events, and sponsorships for the purposes of enhancing brands' identity positioning. According to social-identity research, when identity is accessible, consumers tend to favor stimuli consistent with the accessible identity (Tu et al., 2012) [2]. The reason behind is that consumers prefer to hold positive self-views. Hence, identityconsistent stimuli are considered and processed as more relevant. Tu et al. (2012) [2] suggest that using the knowledge about consumers local-global identity may lead to more effective and identity-consistent communication in personal selling and sales promotions. 
Gammoh et al. (2011) [6] advise marketing practitioners to use the GCCP strategy for consumers who have high level of belief in global citizenship. In order to identify these individuals, the authors suggest the use of Cleveland, \& Laroche's (2007) [13] multifaceted scale that captures acculturation to global consumer cultures. Consumer culture positioning is achieved through the use of language, aesthetic styles, and story themes (Gammoh et al., 2011) [6].

\section{Conclusion}

he present paper focused on the role of cultural diversity in $\langle$ T consumer research. The topic was approached in a nonempirical manner utilizing relevant literature published in the period 2011-2015 in A+ to $C$ ranked journals. Four themes emerged and were integrated into the $4 \mathrm{Cs}$ research taxonomy: Consumer differences, Consumption practices, Complexity in research, and Communication advice for practitioners. Two distinctive streams of research on the topic were also identified. The first one concentrates on biculturals by birth or by migration and the second one investigates attitudes towards cultural diversity trough identity formation. It is noticeable that the articles of the first stream utilize predominantly qualitative research techniques, while the second stream relies on quantitative methods.

Important findings from the first stream are that cultural competence impacts the allocation of decision making roles (Cross, \& Gilly, 2014) [9], biculturals are more willing to consume diverse products (Cross, \& Gilly, 2013) [8], and biculturals react positively toward both individually or interpersonally focused advertising appeals (Lau-Gesk, 2003) [1].

The second stream related to attitudes towards cultural diversity identifies that cultural identity informs consumer behavior. Cultural identity can be measured as national vs. global identity (Bartikowski, \& Walsh, 2015) [7], or as local vs. global identity Tu et al. (2012) [2], or as belief in global citizenship (Gammoh et al., 2011) [6].

A notable criticism towards the examined literature is the lack of connection between the two identified streams of research. The only exception is the study of Kipnis et al. (2012) [4] who differentiate between both migrant vs. mainstream consumers, and the cultural orientations of those individuals. Future research could, therefore, benefit from integrating both perspectives. Experimental research on the topic is only carried out in print media. According to Russell et al. (2013) [5], individuals appropriate cultural diversity available in television narratives through a process of homophilization. This implicates that consumers anticipate aspects of television narratives as similar to their own lived experiences. It is, hence, suggested in the present paper that future experimental research should include broadcast media. In addition, outdoor, in-store, and digital media can also be considered.

\section{Bibliographic references}

1 Lau-Gesk, L. G. Activating culture through persuasion appeals: An examination of the bicultural consumer [Text] / L. G. Lau-Gesk // J.of Consumer Psychology. - 2003. - №13 (3). - P. 301-315.

2. Tu, L. A short 8-item scale for measuring consumers' localglobal identity [Text] / L. Tu, A. Khare, Y.Zhang // International J. of Research in Marketing. - 2012. - №29 (1). - P. 35-42.

3. Woodside, A. G. Cultural diversity and marketing transactions: Are market integration, large community size, and world religions necessary for fairness in ephemeral exchanges? [Text] / A. G. Woodside, M. Zhang // Psychology \& Marketing. - 2013. - №30 (3). - P. 263-276.
4. Kipnis, E. Living Diversity: Developing a Typology of Consumer Cultural Orientations in Culturally Diverse Marketplaces: Consequences for Consumption [Text] / E. Kipnis, J. Emontspool, A. J. Broderick // NA-Advances in Consumer Research. - Volume № 40. - 2012.

5. Russell, C. A. Cultural Diversity in Television Narratives: Homophilization, Appropriation, and Implications for Media Advocacy [Text] / C. A. Russell, H. J. Schau, D. Crockett // J. of Public Policy \& Marketing. - 2013. №32(special issue). - P. 119-130.

6. Gammoh, B. S. Consumer culture brand positioning strategies: an experimental investigation [Text] / B.S. Gammoh, A. C. Koh, S. C. Okoroafo // J. of Product \& Brand Management. - 2011. - №20 (1). - P. 48-57.

7. Bartikowski, B. Attitude toward cultural diversity: A test of identity-related antecedents and purchasing consequences [Text] / B. Bartikowski, G. Walsh // J. of Business Research. - 2015. - №68 (3). - P. 526-533.

8. Cross, S. N. Navigating the diversity within [Text] / S. N. Cross, M. C. Gilly // Research in Consumer Behavior. - 2013. №15. - P. 57-72.

9. Cross, S. N. Cultural competence and cultural compensatory mechanisms in binational households [Text] / S. N. Cross, M. C. Gilly // J. of Marketing. - 2014. - №78 (3). - P. 121139.

10. Alden, D. L. Brand positioning through advertising in Asia, North America, and Europe: The role of global consumer culture [Text] / D. L. Alden, J. B. E. Steenkamp, R. Batra // The J. of Marketing. - 1999. - P. 75-87.

11. Strizhakova, Y. Branded products as a passport to global citizenship: Perspectives from developed and developing countries [Text] / Y. Strizhakova, R. A. Coulter, L. L. Price // J. of International Marketing. - 2008. - №16 (4). - P. 5785.

12. Data equivalence in cross-cultural international business research: assessment and guidelines [Text] / G. T. Hult [et al.] // J. of International Business Studies. - 2008. №39 (6). - P. 1027-1044.

13. Cleveland, M. Acculturaton to the global consumer culture: Scale development and research paradigm [Text] / M. Cleveland, M. Laroche // J. of business research. 2007. - №60 (3). - P. 249-259.

\section{References}

Alden, D. L., Steenkamp, J. B. E., \& Batra, R. (1999). Brand positioning through advertising in Asia, North America, and Europe: The role of global consumer culture. The Journal of Marketing, 75-87.

Bartikowski, B., \& Walsh, G. (2015). Attitude toward cultural diversity: A test of identity-related antecedents and purchasing consequences. Journal of Business Research, 68(3), 526-533.

Cleveland, M., \& Laroche, M. (2007). Acculturaton to the global consumer culture: Scale development and research paradigm. Journal of business research, 60(3), 249-259.

Cross, S. N., \& Gilly, M. C. (2013). Navigating the diversity within. Research in Consumer Behavior, 15, 57-72.

Cross, S. N., \& Gilly, M. C. (2014). Cultural competence and cultural compensatory mechanisms in binational households. Journal of Marketing, 78(3), 121-139. 
Gammoh, B. S., Koh, A. C., \& Okoroafo, S. C. (2011). Consumer culture brand positioning strategies: an experimental investigation. Journal of Product \& Brand Management, 20(1), 48-57.

Hult, G. T. M., Ketchen Jr, D. J., Griffith, D. A., Finnegan, C. A., Gonzalez-Padron, T., Harmancioglu, N., ... \& Cavusgil, S. T. (2008). Data equivalence in cross-cultural international business research: assessment and guidelines. Journal of International Business Studies, 39(6), 1027-1044.

Kipnis, E., Emontspool, J., \& Broderick, A. J. (2012). Living Diversity: Developing a Typology of Consumer Cultural Orientations in Culturally Diverse Marketplaces: Consequences for Consumption. NA-Advances in Consumer Research Volume 40.

Lau-Gesk, L. G. (2003). Activating culture through persuasion appeals: An examination of the bicultural consumer. Journal of Consumer Psychology, 13(3), 301-315.
Russell, C. A., Schau, H. J., \& Crockett, D. (2013). Cultural Diversity in Television Narratives: Homophilization, Appropriation, and Implications for Media Advocacy. Journal of Public Policy \& Marketing, 32(special issue), 119-130.

Strizhakova, Y., Coulter, R. A., \& Price, L. L. (2008). Branded products as a passport to global citizenship: Perspectives from developed and developing countries. Journal of International Marketing, 16(4), 57-85.

Tu, L., Khare, A., \& Zhang, Y. (2012). A short 8-item scale for measuring consumers' local-global identity. International Journal of Research in Marketing, 29(1), 35-42.

Woodside, A. G., \& Zhang, M. (2013). Cultural diversity and marketing transactions: Are market integration, large community size, and world religions necessary for fairness in ephemeral exchanges? Psychology \& Marketing, 30(3), 263-276. 